\title{
EXPERIMENTALWORKS
}

UDC $612.35: 612.26: 577.23$

doi: https://doi.org/10.15407/ubj91.06.005

\section{DEPENDENCE OF THE MITOCHONDRIAL ADAPTIVE CAPACITY OF HEPATOCYTES ON THE OXIDATIVE SUBSTRATES AVAILABILITY}

\author{
H. M. MAZUR, V. M. MERLAVSKY, B. O. MANKO, V. V. MANKO \\ Ivan Franko National University of Lviv, Ukraine; \\ e-mail: Volodymyr.Manko@lnu.edu.ua
}

Received: 11 February 2019; Accepted: 18 October 2019

The ability of the mitochondria to compensate for energy expenditure of cells largely depends on the availability of the oxidative substrates, transported across the intact plasma membrane with molecular carriers of limited affinity. The aim of this study was to investigate the dependence of adaptive respiratory responses of mitochondria of intact hepatocytes on the oxidative substrates. Basal and FCCP-stimulated respiration rates were determined with Clark electrode. After 15-minute incubation in the medium with the oxidative substrates or their combinations (glutamine, pyruvate, succinate, monomethyl succinate, $\alpha$-ketoglutarate, dimethyl- $\alpha$-ketoglutarate $(2 \mathrm{mM})$ or glucose $(10 \mathrm{mM}))$, isolated hepatocytes were added into the respiratory chamber. FCCP concentration was $0.25,0.5$ and $1 \mu \mathrm{M}$. The adaptive capacity of mitochondria was characterized by the maximal uncoupled respiration rate (the highest respiration rate among all tested FCCP concentrations), the optimal FCCP concentration (the concentration at which the maximal rate is achieved) and the area under the curve (AUC) of the dependence of the uncoupled respiration rate on FCCP concentration. The adaptive capacity of mitochondria, evaluated by AUC, increases in this order of substrates: glucose (0.063 r.u.), endogenous substrates (0.067 r.u.), glutamine (0.092 r.u.), pyruvate (0.113 r.u.), a-ketoglutarate (0.113 r.u.), succinate (0.152 r.u.), dimethyl- $\alpha$-ketoglutarate (0.156 r.u.), and monomethyl succinate (0.172 r.u.). The adaptive capacity of mitochondria of hepatocytes seems to be partly dependent on plasma membrane transporters affinities $\left(K_{m}\right)$ to the oxidative substrates. The presence of glucose in the medium does not improve the adaptive capacity of hepatic mitochondria.

Ke y w o rd s: adaptive capacity of mitochondria, oxidative substrates, hepatocytes, FCCP.

I $\mathrm{n}$ the resting state, the mitochondria of living cells carry out oxidative processes at a low baseline, using only the part of their adaptive capacity. However, in the case of high workload or stress, cells require an additional amount of energy. Mitochondria can compensate for energy expenditure of cells by enhancing the work of the respiratory chain. The limit of the respiratory response defines the mitochondrial adaptive capacity.

The adaptive capacity of mitochondria can be estimated by inducing the adaptive respiratory response to the mitochondrial proton gradient dissi- pation with protonophores (CCCP or FCCP). It has been shown that reduction of the adaptive capacity (as measured by the reserve respiratory capacity the difference between maximal uncoupled and basal respiration rates) of mitochondria correlates with various pathologies, including neurodegenerative disorders [1, 2], heart disease [3], as well as smooth muscles cell death [4].

The energy depletion in hepatocytes is often caused by mitochondria dysfunctions. While not as detrimental as in other organs, mitochondrial diseases also are causes of liver malfunction. For

(c) 2019 Mazur H. M. et al. This is an open-access article distributed under the terms of the Creative Commons Attribution License, which permits unrestricted use, distribution, and reproduction in any medium, provided the original author and source are credited. 
example, Pearson syndrome is characterized by liver fibrosis, cholestasis and hepatocellular hemosiderosis [5]. Structural and functional changes of mitochondria during non-alcoholic fatty liver disease also cause energy depletion of hepatocytes [6]. Chronic fructose diet may be a cause of ATP depletion, which may increase the risk for inflammation and scarring in the liver [7]. Detailed study of bioenergetic processes in mitochondria of the liver will allow the timely detection of pathologies associated with mitochondrial dysfunction.

In isolated mitochondria, the adaptive respiratory response depends on the properties of the respiratory chain of mitochondria and activity of tricarboxylic acid cycle enzymes. However, in intact cells, oxidative substrates need to first cross the plasma membrane in order to be utilized by mitochondria. Different cells types have substrate transporters with different affinities $\left(K_{\mathrm{m}}\right)$. In hepatocytes, transport of glucose across the plasma membrane is carried out by GLUT transporters family [8]. Pyruvate is transported by monocarboxylate transporters (MCT) [9]. Glutamine is transported into hepatocytes by $\mathrm{Na}^{+}-$ dependent (SNAT) and $\mathrm{Na}^{+}$-independent systems [10]. The transport of tricarboxylic acid cycle intermediates, such as succinate and $\alpha$-ketoglutarate, is carried out by $\mathrm{Na}^{+}$-dicarboxylate cotransporters (NaDC) [11]. Thus we assume that adaptive respiratory response of mitochondria in intact cells largely depends on the transport of oxidative substrates across the intact plasma membrane with molecular carriers of limited affinity and capacity.

The aim of this study was to investigate the dependence of adaptive respiratory responses to FCCP of mitochondria of intact hepatocytes on the oxidative substrates.

\section{Materials and Methods}

Reagents used in experiments were purchased from Sigma-Aldrich (sodium chloride S7653, glucose G8270, N-2-hydroxyethylpiperazine-N'-2ethanesulfonic acid (HEPES) H3375, bovine serum albumin (BSA) A6003, succinate S3674, sodium pyruvate P2256, glutamic acid 49449, mono-methyl-succinate M81101, D-methyl-2-oxoglutarate 349631, $\alpha$-ketoglutaric acid K1875, succinic acid S3674, ethylene glycol-bis(2-aminoethylether)-N, $\mathrm{N}, \mathrm{N}, \mathrm{N}$-tetraacetic acid (EGTA), carbonyl cyanide4-(trifluoromethoxy) phenylhydrazone (FCCP) C2920, collagenase type IV C5138) or Merck Chemicals (Calcium chloride dihydrate). All other reagents were of purest available grade.
All manipulations with animals were carried out according to the European Convention for the protection of vertebrate animals used for experimental and other scientific purposes (Strasbourg, 1986) and the First National Congress of Ukraine on Bioethics (September 2001).

Experiments were performed on white wildtype rats weighing 250-300 g. The animals were kept in stationary vivarium conditions at a constant temperature and the standard diet. Before the experiment, the animals starved for 18 hours with free access to water. Animals were anesthetized with sodium thiopental ( $40 \mathrm{mg} / \mathrm{kg}$ body weight) by intraperitoneal administration. To check anesthesia state, the tail was pressed with the tweezers. Anesthetized animal was fixed in the back position and abdominal dissection was made. Heparin $5000 \mathrm{IU} / \mathrm{ml}(0.3 \mathrm{ml})$ was injected into the abdominal inferior vena cava to prevent blood clots. A catheter was inserted into the portal vein $(18 \mathrm{G}, 1.3 \times 45 \mathrm{~mm})$ and incision of the inferior vena cava for a solution outflow was made. To wash out the blood, the liver was perfused with calcium-free EGTA-containing extracellular solution at $37{ }^{\circ} \mathrm{C}$ containing, $\mathrm{mM}: \mathrm{NaCl}-140.0, \mathrm{KCl}-4.7$, glucose - 5.0, HEPES - 10.0, EGTA - 1.0; pH 7.4. The solutions flux velocity was stable and was approximately $20 \mathrm{ml} / \mathrm{min}$.

At the next stage, recirculating perfusion of the liver with calcium-containing collagenase solution (108 units $/ \mathrm{ml})$ was performed for $10-12 \min \left(37^{\circ} \mathrm{C}\right)$ [12]. This solution contains, $\mathrm{mM}: \mathrm{NaCl}-140.0$, $\mathrm{KCl}$ - 4.7, $\mathrm{CaCl}_{2}-3$, glucose - 5.0; HEPES - 10.0; $\mathrm{pH}$ 7.6. The chest of the animal was opened and the outflow catheter $(16 \mathrm{G}, 1.7 \times 45 \mathrm{~mm})$ was inserted through the right atrium, through which the outflow of solution occurred, and ligature was performed on the abdominal inferior vena cava proximally to the incision. After the digestion of the collagen matrix, the liver was transferred to the basic extracellular medium at $20{ }^{\circ} \mathrm{C}$ containing, $\mathrm{mM}: \mathrm{NaCl}-140.0$, $\mathrm{KCl}-4.7, \mathrm{CaCl}_{2}-1.3, \mathrm{MgCl}_{2}-1.0$, glucose -5.0 , HEPES - 10.0; pH 7.4.

Afterwards, isolated hepatocytes were dispersed by gentle pipetting. To exclude clots of the cells, suspension was filtrated through the nylon mesh $(0.45 \mu \mathrm{m})$. To remove metabolites, residues of extracellular matrix and damaged hepatocytes, the cells were washed three times with centrifugation at $50 \mathrm{~g}$. Hepatocytes were counted with haemocytometer. The plasma membrane integrity of hepatocytes was evaluated by staining the cells with a $0.1 \%$ 
trypan blue solution. The number of intact cells was $82.29 \pm 1.79 \%$ from the total.

Oxygen consumption rate was determined with Clark electrode (oxygen monitor YSI 5300) in $1.6 \mathrm{ml}$ thermostatic glass chamber at $37^{\circ} \mathrm{C}$. Approximately 2 million of cells suspended in the basic glucosefree solution were introduced into the respiratory cell. Alternatively, solution was supplemented with glucose $(10 \mathrm{mM})$, glutamine, pyruvate, succinate, monomethyl succinate, $\alpha$-ketoglutarate or dimethyl$\alpha$-ketoglutarate ( $2 \mathrm{mM}$ ), or a combination of these substrates. The details of the experimental design are described in the Results section.

Mathematical and statistical analysis of the data was performed using the software package Microsoft Excel. Statistical significance of difference between groups was determined with Student's $t$-test and $P<0.05$.

\section{Results and Discussion}

Dependence of the respiration rate of hepatocytes on the exogenous glucose, pyruvate and glutamine. The adaptive capacity of mitochondria is limited by the activity of both TCA cycle and respiratory chain enzymes. In turn, the TCA cycle enzymes activities depend on their substrates availability, and thus, expression of substrate transporters, their localization in the cell membranes, and their affinities. Pyruvate, a product of glycolysis, and glutamine are the most important substrates that supply TCA cycle. Therefore, it is important to investigate their contribution to the adaptive capacity of mitochondria.

To investigate the respiratory responses, isolated hepatocytes were incubated for $15 \mathrm{~min}$ at $37^{\circ} \mathrm{C}$ with exogenous oxidative substrates or without them (control, endogenous substrates). Further, cells were added into the respiratory chamber and basal respiration rate was recorded. Then, FCCP was added into the respiratory chamber in increasing concentrations - up to $0.25,0.5$ or $1 \mu \mathrm{M}$ (Fig. $1, A$ ).

The basal respiration rate of hepatocytes was $0.12 \pm 0.02 \mathrm{nmol} \mathrm{O}_{2} /\left(\mathrm{s} \times 10^{6}\right.$ cells $)$ upon oxidation of endogenous substrates (Fig. 1, B). Tyhe oxygen consumption rate of hepatocytes increased after adding $0.25 \mu \mathrm{M}$ FCCP. Further increases of FCCP concentration to 0.5 and $1 \mu \mathrm{M}$ did not result in any change of oxygen consumption rate. Adding glucose to the basal medium did not significantly change the rates of basal and FCCP-stimulated respiration of hepatocytes when compared to oxidation of endogenous substrates (Fig. 1, $B$ ).
Glucose is transported into the cells across the plasma membrane by GLUT transporter family. Despite the fact, that GLUT-1, GLUT-2, GLUT-3 and GLUT-5 are expressed in rat hepatocytes [13], glucose in these cells is transported, apparently, preferentially by GLUT-2 [13-15], located on the sinusoidal membrane of rat hepatocytes [16]. After glucose uptake by hepatocytes, it might be phosphorylated to glucose-6-phosphate and metabolized to the pyruvate via the glycolysis pathway. Pyruvate might enter various anabolic and catabolic pathways such as gluconeogenesis, lipid and cholesterol synthesis or oxidative metabolism [17]. Alternatively, glucose is phosphorylated to glucose-1-phosphate and deposited in the liver as glycogen [18]. The rate of respiration upon glucose presence reveals only the flux of complete glucose oxidation, which is only the part of glucose utilization capacity of hepatocytes.

Pyruvate significantly increased basal and FCCP-stimulated respiration rates at all concentrations of this protonophore when compared to the respective endogenous respiration rates (Fig. 1, B). Consequently, in hepatocytes, pyruvate oxidation provides a higher mitochondrial adaptive capacity than glucose oxidation. Therefore, it can be assumed that glycolysis is a limiting stage of glucose catabolism in hepatocytes. Moreover, the effects of glucose $(10 \mathrm{mM})$ and pyruvate $(2 \mathrm{mM})$ were non-additive, since at simultaneous presence of these substrates in the medium basal and FCCP-stimulated respiration rates did not differ from the rates upon sole pyruvate presence.

Exogenous pyruvate (as well as lactate or ketone bodies) is transported into the cell across the plasma membrane by monocarboxylate transporters (MCTs). On Xenopus laevis oocytes $K_{\mathrm{m}}$ of MCT-1 and MCT-2 for pyruvate are 1-2 and 0.025$0.08 \mathrm{mM}$, respectively [19]. The low $K_{\mathrm{m}}$ values of MCT for pyruvate thus easily enable the sufficient pyruvate transport to support high respiration rate in our experiments.

We have found that glutamine did not affect the basal rate of oxygen consumption, but increased the rate of FCCP-stimulated respiration at 0.5 and $1 \mu \mathrm{M}$ of protonophore comparing to control (Fig. 1, C). Apparently, plasma membrane glutamine transporters with relatively high affinity [10] supply rat hepatocytes with sufficient amounts of glutamine which enters the citric acid cycle via conversion to glutamate and maintains the mitochondrial respiration at high level. 

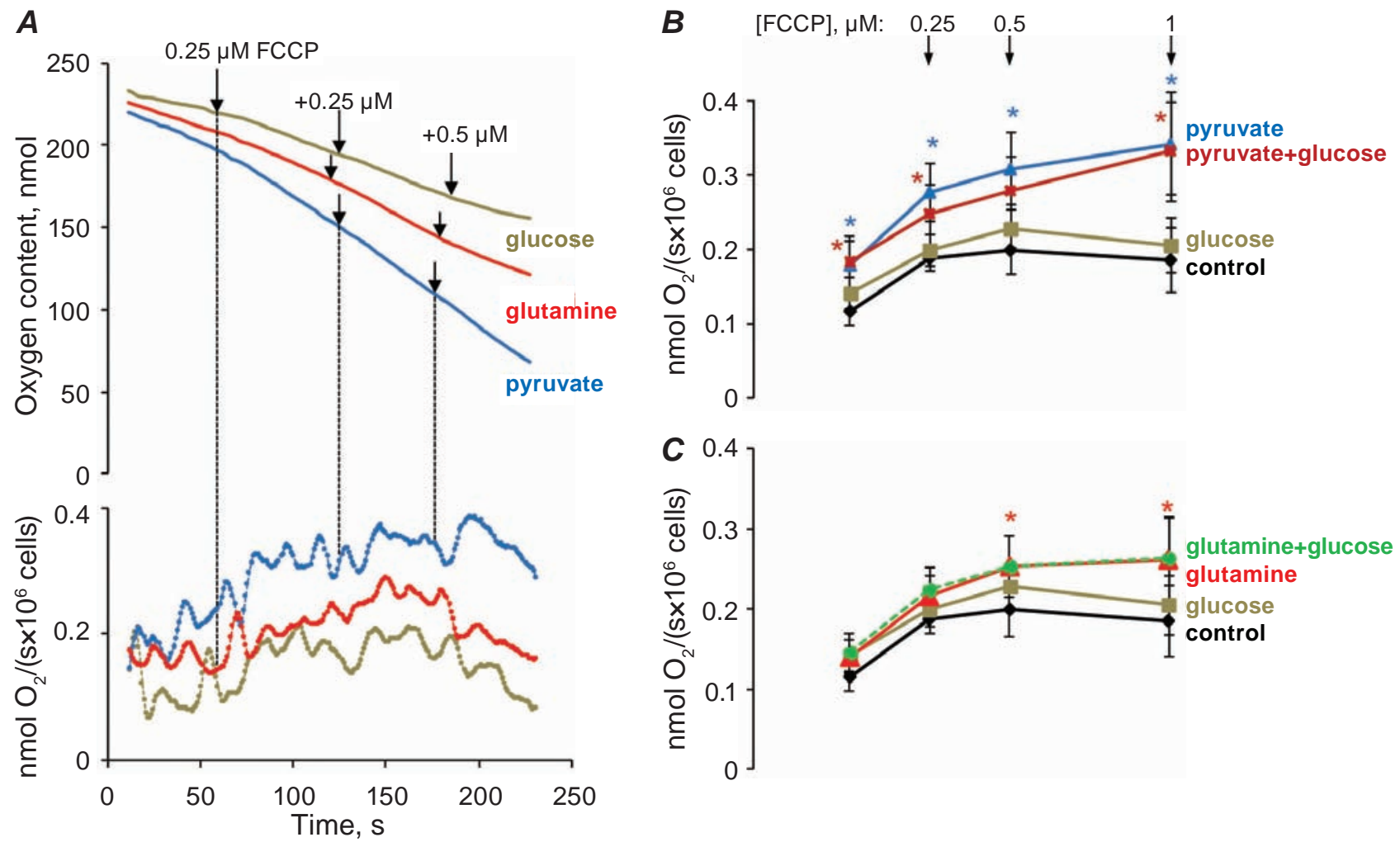

Fig. 1. The respiration rate of intact hepatocytes depends on the substrate of oxidation: $\mathbf{A}$ - original recording of oxygen consumption by the hepatocytes suspension (top) and calculated momentary respiration rate (bottom) upon the oxidation of exogenous pyruvate, glutamine and glucose; Arrows indicate the time of adding the FCCP into the chamber to a final concentration of $0.25,0.5$ and $1 \mu \mathrm{M} ; \boldsymbol{B}, \boldsymbol{C}$-dependence of intact hepatocytes respiration on the concentration of FCCP; [glucose] $=10 \mathrm{mM}$, [pyruvate], [glutamine] $=2 \mathrm{mM}$; * statistically significant difference comparing to the endogenous substrates $(\boldsymbol{B}, \boldsymbol{C})$ with $P<0.05, n=6$

Glutamine can be transported across the plasma membrane of isolated rat hepatocytes by $\mathrm{Na}^{+}$-dependent and $\mathrm{Na}^{+}$-independent systems. The latter can also transport glutamine from cells if its intracellular concentration increases [10]. Baird and coauthors [20] detected two SNAT isoforms in the rat liver SNAT3 and SNAT5. This in situ hybridization study has shown that SNAT5 mRNA is predominantly expressed in periportal hepatocytes [20] and provides glutamine uptake from the portal blood transferring NH3 in the form of glutamine for further conversion into urea in the liver [21]. The expression of SNAT3 mRNA was mainly concentrated within the perivenous region bordering central veins [20]. This transporter provides release of glutamine from hepatocytes into the venous blood flow.

As in the case of pyruvate, combination of glutamine with glucose did not result in any further significant changes of respiration rates. Apparently, the formation of pyruvate from glucose was too slow to affect these parameters significantly.
Oxygen consumption by hepatocytes incubated with succinate, $\alpha$-ketoglutarate and their methyl esters. The transport of tricarboxylic acid cycle intermediates, such as succinate and $\alpha$-ketoglutarate, is mainly carried out by $\mathrm{Na}^{+}$-dicarboxylate cotransporter (NaDC) with $K_{\mathrm{m}}$ 5-30 $\mu \mathrm{M}$ [22]. Histoauthoradiography of perfused rat liver has shown that the uptake of vascular $\alpha$-ketoglutarate is carried out by perivenous glutamine synthase containing hepatocytes, possibly by $\mathrm{Na}^{+}$-dicarboxylate transporters $[23,24]$. The expression of NaDC-3 mRNA in rat hepatocytes surrounding the central vein was confirmed by in situ hybridization [25].

Rognstad has shown that penetration of the succinate into the cell across the plasma membrane can be enhanced by using a more lipophilic form of succinate - its methyl ester [26]. However, the capability of methyl esters of the TCA cycle substrates to support the energy processes in isolated hepatocytes after demethylation with cellular esterases was not investigated yet. 

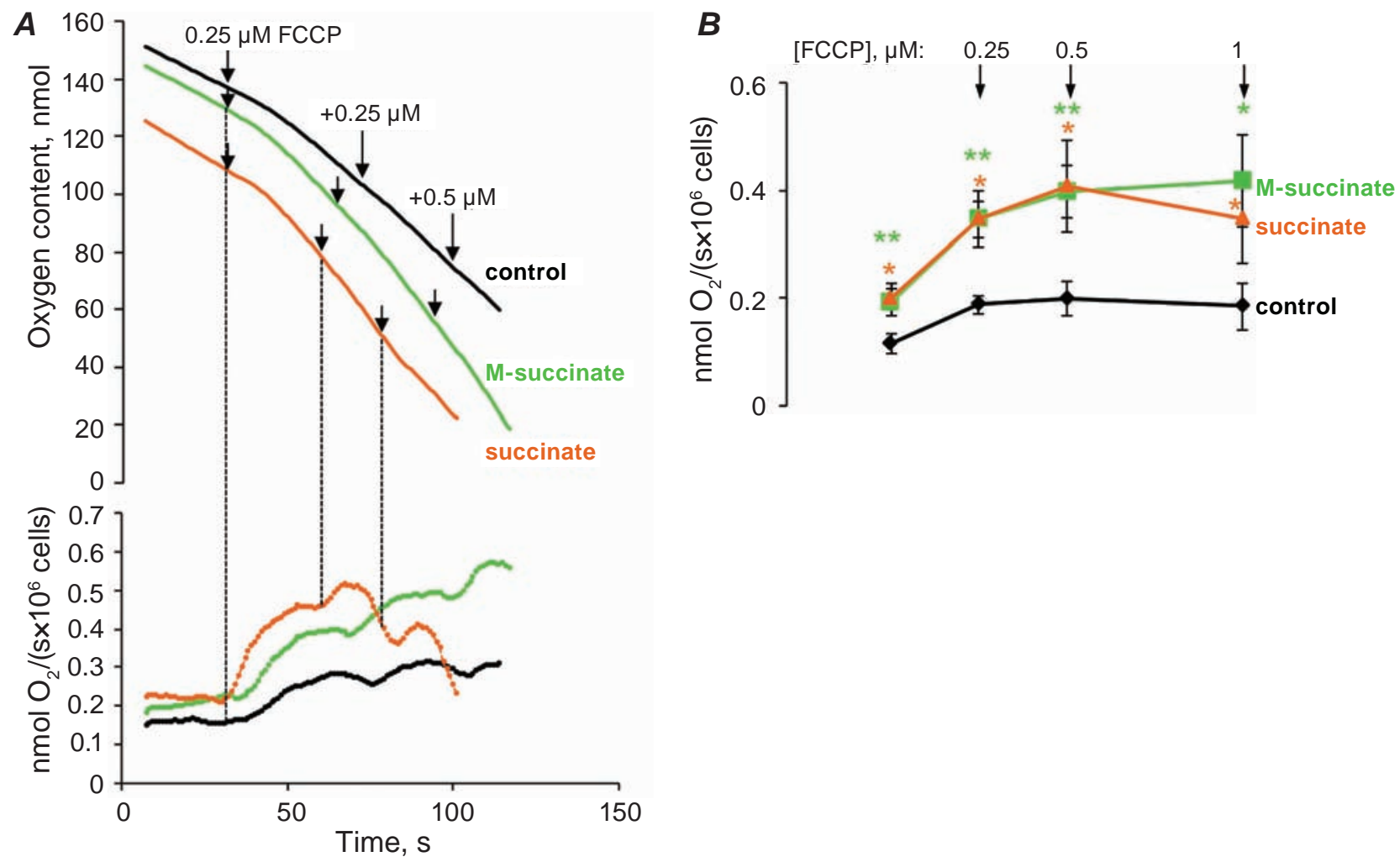

Fig. 2. The respiration rate of hepatocytes using of succinate and its methyl derivative: $\mathbf{A}$ - original recording of oxygen consumption by the hepatocytes suspension (top) and calculated momentary respiration rate (bottom) upon succinate oxidation; arrows indicate the time of adding the FCCP into the chamber to a final concentration of $0.25,0.5$ and $1 \mu \mathrm{M} ; \boldsymbol{B}$ - dependence of intact hepatocytes respiration from the concentration of FCCP in the medium; [succinate], [monomethyl succinate] = $2 \mathrm{mM} ; *$ statistically significant difference in respiration rate of endogenous substrates oxidation (B) with $P<0.05, n=6$

We found that the addition of succinate or monomethyl succinate increased the rate of basal oxygen consumption by hepatocytes (Fig. 2), whereas $\alpha$-ketoglutarate and dimethyl- $\alpha$-ketoglutarate did not affect this rate (Fig. 3).

The uncoupled respiration rate of hepatocyte at $0.25,0.5$ and $1 \mu \mathrm{M}$ FCCP was higher in the presence of succinate, monomethyl succinate and dimethyl- $\alpha$ ketoglutarate compared to control. Upon exogenous $\alpha$-ketoglutarate oxidation, the rate of uncoupling respiration increased only at $0.25 \mu \mathrm{M}$ FCCP.

The methyl esters of succinate and $\alpha$-ketoglutarate support respiration of hepatocytes at the same level as succinate and $\alpha$-ketoglutarate. However, at the concentrations of FCCP of $1 \mu \mathrm{M}$, the respiration rate of hepatocyte was higher when using methyl esters of substrates, which might be due to their better penetration into the cells.

The succinate and $\alpha$-ketoglutarate are transported by one type of transporters. The higher respiration rates observed upon succinate oxidation com- pared to $\alpha$-ketoglutarate oxidation may be due to the differences of selectivity of the transporters to these substrates, of the rates of inclusion of the substrates into the TCA cycle, of the TCA cycle dehydrogenases activities, of the efficiencies of proton transport by the respiratory chain or/and other factors.

The components of adaptive respiratory response of mitochondria of intact hepatocytes upon oxidation of various substrates. The adaptive respiratory response of mitochondria in hepatocytes can be characterized by the maximal rate of uncoupled respiration (the highest respiration rate among all FCCP concentrations tested in each experiment) and the optimal concentration of FCCP - the concentration at which the maximal rate is achieved.

The maximal rate of uncoupled respiration in the medium without oxidative substrates was $0.22 \pm 0.05 \mathrm{nmol} \mathrm{O} /\left(\mathrm{s} \times 10^{6}\right.$ cells) (Fig. $\left.4, A\right)$, and the optimal FCCP concentration $-0.57 \pm 0.15 \mu \mathrm{M}$ (Fig. 4, B). 

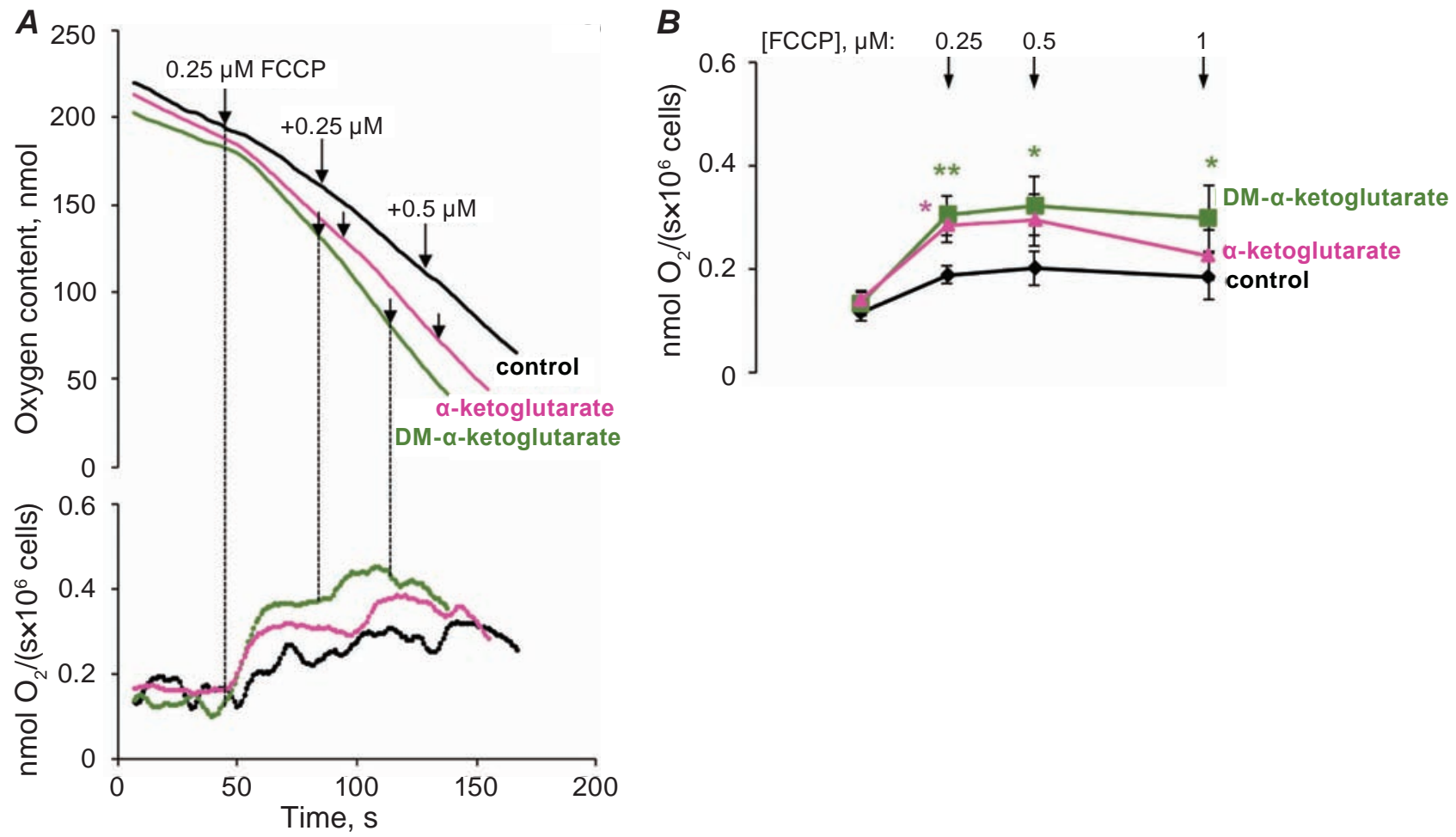

Fig. 3. The respiration rate of hepatocytes at the use of $\alpha$-ketoglutarate or dimethyl- $\alpha$-ketoglutarate: $\boldsymbol{A}-$ original recording of oxygen consumption by the hepatocytes suspension (top) and calculated momentary respiration rate (bottom) upon $\alpha$-ketoglutarate or dimethyl- $\alpha$-ketoglutarate oxidation; arrows indicate the time of adding the FCCP into the chamber to a final concentration of 0.25, 0.5 and $1 \mu \mathrm{M} ; \boldsymbol{B}$-dependence of intact hepatocytes respiration from the concentration of FCCP in the medium; [ $\alpha$-ketoglutarate], [dimethyl$\alpha$-ketoglutarate] $=2 \mathrm{mM}$; *statistically significant difference in respiration rate of endogenous substrates oxidation (B) with $P<0.05, n=6$

The presence of exogenous oxidative substrates in the medium caused a pronounced tendency to increase of the maximal uncoupled respiration rate. But these increases reached the required level of significance only with the use of dimethyl- $\alpha$ ketoglutarate, succinate and monomethyl succinate (Fig. 4, A). One-factor ANOVA test confirmed the statistically significant effect of substrates on the maximal uncoupled respiration rate with $P=0.036$. The highest maximal uncoupled respiration rate was upon monomethyl succinate oxidation, and decreased in sequence: monomethyl succinate $\approx$ succinate $>$ pyruvate $\approx$ dimethyl $\alpha$-ketoglutarate $\approx \alpha$-ketoglutarate $>$ glutamine $>$ glucose.

In the case of an optimal concentration of FCCP, the sequence of substrates was different (Fig. 4 B). The optimal concentration of FCCP upon $\alpha$-ketoglutarate and succinate oxidation was substantially lower than upon pyruvate or glutamine oxidation. Obviously, this parameter characterizes the stability of respiration processes or the time during which the substrates are able to maintain the respiration at a high level upon the increase of FCCP concentration. Apparently, after 15-min incubation with succinate or $\alpha$-ketoglutarate, their pool in the mitochondrial matrix was still low. One of the reasons for this could be a low rate of substrate transport across the plasma membrane. This is consistent with the fact that the optimal concentration of FCCP after incubation with methyl esters of these substrates was slightly higher.

Interestingly, the addition of glucose to a medium that already contained pyruvate not only did not increase, but even somewhat decreased the average arithmetic mean of the maximal uncoupled respiration rate (Fig. 4, A). Similarly, the tendency to decrease the maximal rate of uncoupled respiration was observed at the presence of a mixture of glutamine and glucose in the medium. Addition of glucose to the pyruvate-containing or glutaminecontaining medium also did not affect the optimal concentration of FCCP (Fig. 4, B). Consequently, the 
A

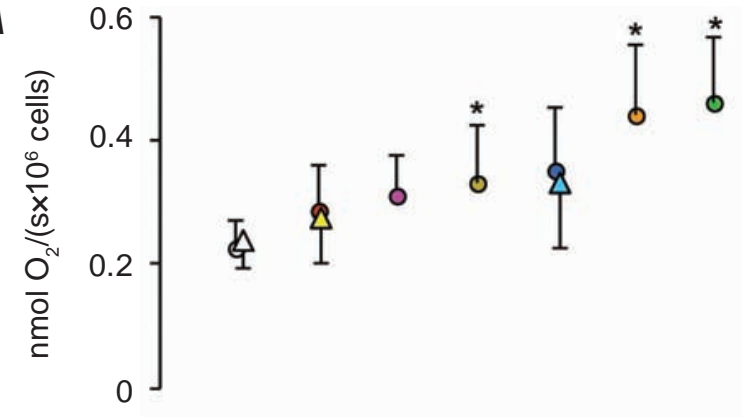

B

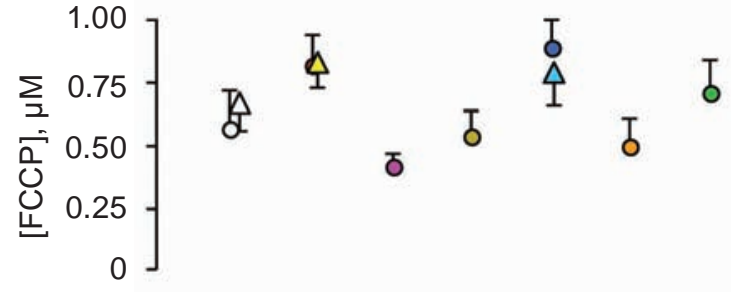

C

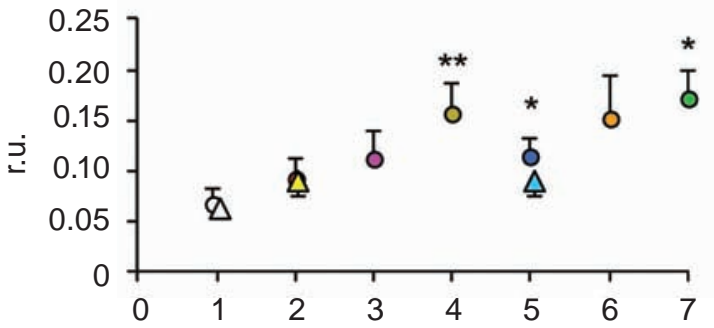

Fig. 4. The effect of substrates on maximal uncoupled respiration rate (A), optimal concentration of FCCP (B) and area under the curve (C): 1 - endogenous substrates, 2 - glutamine, 3 - $\alpha$-ketoglutarate, 4 -dimethyl-a-ketoglutarate, 5 -pyruvate, 6 -succinate, 7 - monomethyl succinate; 0 - without glucose, $\Delta$ - combination with glucose; * statistically significant difference in respiration rate of endogenous substrates oxidation with $P<0.05, n=6$

presence of glucose at high concentration does not improve the adaptive respiratory response of mitochondria.

In fact, the adaptive capacity of mitochondria is the capacity of the catabolic processes to respond to the depolarization of their inner membrane. The decrease of the potential of inner mitochondrial membrane is observed during the functional loads of cells, when energy, stored as an electrochemical gradient of $\mathrm{H}^{+}$, is rapidly used for ATP synthesis. The response is aimed for the restoring of the membrane potential. The limit of this response determines the ability of cells to perform a particular workload, and ultimately - their viability.

It should be noted that mitochondria of different tissues or at different functional states of the cell may be differently adapted to use the oxidative sub- strates. And hence the basal respiration rate upon their oxidation is different. In particular, we have found that the basal respiration rates of hepatocyte mitochondria upon succinate and pyruvate oxidation were significantly higher than upon oxidation of other substrates (see Fig. 1, B, C, Fig. 2, B and Fig. 3, $B$ ). Since the adaptive capacity of the mitochondria should be defined by the uncoupled, not basal respiration rates, the differences in the latter might complicate the interpretation of the results.

To formalize the assessment of the adaptive capacity of the mitochondria and to avoid dependence on the basal respiration rate, we subtracted the basal respiration rate and calculated the area under the curves of the dependence of the uncoupled respiration rate on FCCP concentration in the studied range:

$$
S=\int_{0}^{1} \Delta v_{i}(C) \cdot d C,
$$

where $S$ - area under the curve, AUC (nmol $\mathrm{O}_{2} \times \mu \mathrm{M}$ $\mathrm{FCCP} /\left(\mathrm{s} \times 10^{6}\right.$ million cells)) or, to simplify the results presentation, r.u., $\Delta v_{i}$ is the increase in the respiration rate at a certain concentration of FCCP $\left(\Delta v_{i}=v_{i}-v_{0} ; \mathrm{nmol} \mathrm{O}_{2} /\left(\mathrm{s} \times 10^{6}\right.\right.$ cells $\left.)\right), C$ - concentration of FCCP $(\mu \mathrm{M})$.

We have proposed an integral AUC to better account for both maximal and sub-maximal hepatocyte respiration rates in response to different concentrations of FCCP. The AUC increased at this order of substrates: glucose (0.063 r.u.), endogenous substrates (0.067 r.u.), glutamine (0.092 r.u.), pyruvate (0.113 r.u.), $\alpha$-ketoglutarate (0.113 r.u.), succinate (0.152 r.u.), dimethyl- $\alpha$-ketoglutarate (0.156 r.u.), monomethyl succinate (0.172 r.u.) (Fig. 1, $C)$. One-factor ANOVA test confirmed the statistically significant effect of substrates on the AUC with $P=0.012$.

The AUC of respiration rate was higher for methyl esters of succinate and $\alpha$-ketoglutarate than for free substrates. Thus, the transport rates of free substrates through the plasma membrane limit sustainability of the adaptive respiratory response. Although there is no unambiguous answer how methyl esters of these substrates are transported across the plasma membrane, presumably they enter the cells by diffusion through the lipid bilayer, or/and via the dicarboxylate transporters with higher affinity for these esters [26]. 
Succinate and $\alpha$-ketoglutarate provide the adaptive capacity of mitochondria at a relatively high level. Succinate supports oxidative processes in mitochondria of intact hepatocytes better than $\alpha$-ketoglutarate, which correlates with higher $\mathrm{Na}^{+}-$ dicarboxylate transporters (NaDC) to it: $K_{\mathrm{m}}$ for succinate is $\sim 6.4 \mu \mathrm{M}$, and for $\alpha$-ketoglutarate $\sim 10 \mu \mathrm{M}$ [11].

Pyruvate is transported across the plasma membrane by monocarboxylate transporters [9] with a fairly high affinity ( $K_{\mathrm{m}}$ from 0.6 [27] to $1.3 \mathrm{mM}$ [28]) and provides the adaptive capacity of the mitochondria at a relatively high level.

Glutamine provides the adaptive capacity of mitochondria at mediocre level. Glutamine is transported across the plasma membrane of rat hepatocytes by SNAT with $K_{\mathrm{m}} 1.25 \mathrm{mM}$ and $\mathrm{Na}^{+}$-independent systems - with $K_{\mathrm{m}} 4 \mathrm{mM}$ [10]. Glutamine enters the tricarboxylic acid cycle by converting to glutamate and $\alpha$-ketoglutarate, bypassing the initial slow stages of the tricarboxylic acid cycle. Nevertheless, the adaptive capacity of hepatocyte mitochondria for its oxidation is not very high, and basal respiration rate is relatively low.

The lowest adaptive capacity of mitochondria of hepatocyte is upon glucose oxidation, which is transported across the plasma membrane with low-affinity GLUT-2 transporter [13, 29] with $K_{\mathrm{m}} \sim 17 \mathrm{mM}$ [16]. The other reasons for the low adaptive capacity of mitochondria upon glucose oxidation might be the peculiarities of its metabolism in hepatocytes, since the main function of the liver is the storage of glucose in the form of glycogen, not its oxidation.

The substrate transport rate into cells depends not only on the affinity of the transporters but also on transporting capacity and the amount of these transporters. In particular, $\alpha$-ketoglutarate transporters are strongly expressed only in the subpopulation of perivenous glutamine synthase containing hepatocytes [23]. As we studied the entire population of hepatocytes, the $\alpha$-ketoglutarate transport was largely limited, as confirmed by experiments with the methyl ester of this substrate.

Thus, the adaptive capacity of hepatocytes dependence on oxidative substrate type might be partly explained by plasma membrane transport, not only by the mitochondrial oxidative processes.
Conflict of interest. Authors have completed the Unified Conflicts of Interest form at http://ukrbiochemjournal.org/wp-content/uploads/2018/12/ coi_disclosure.pdf and declare no conflict of interest.

\section{ЗАЛЕЖНІСТЬ АДАПТАЦІЙНОЇ ЗДАТНОСТІ МІТОХОНДРІЙ ГЕПАТОЦИТІВ ВІД ДОСТУПНОСТІ СУБСТРАТІВ ОКИСЛЕННЯ}

\author{
Г. М. Мазур, В. М. Мерлавський, \\ Б. О. Манько, В. В. Манько
Львівський національний університет імені Івана Франка, Україна;
e-mail: Volodymyr.Manko@lnu.edu.ua

Здатність мітохондрій компенсувати енергетичні витрати клітини значною мірою залежить від доступності субстратів окислення, транспортування яких крізь плазматичну мембрану здійснюється транспортерами 3 різною спорідненістю. Метою роботи було дослідити залежність адаптаційної дихальної відповіді мітохондрій ізольованих гепатоцитів від субстратів окислення. Швидкість базального i FCCP-стимульованого дихання визначали за допомогою електрода Кларка. Після 15 хв інкубації у середовищах з глюкозою (10 мМ) і відповідним субстратом окислення (глутаміном, піруватом, сукцинатом, монометил-сукцинатом, $\alpha$-кетоглутаратом, диметил- $\alpha$-кетоглутаратом (2 мМ) або їх комбінацією, ізольовані гепатоцити вносили в полярографічну комірку. FCCP додавали в концентраціях $0,25,0,5$ та 1 мкМ. Адаптаційну здатність мітохондрій гепатоцитів характеризували максимальною швидкістю роз'єднаного дихання (найвище значення швидкості дихання за протестованих концентрацій FCCP), оптимальною концентрацією FСCP (концентрацією, за якої ця швидкість зареєстрована), прискоренням дихання внаслідок додавання FCCP та площею приросту під кривими залежності швидкості дихання від концентрації FCCP. Встановлено, що адаптаційна здатність мітохондрій, визначена за площею під кривою, збільшується в такому порядку субстратів: глюкоза (0,063 у.о.), ендогенні субстрати (0.067 у.о.), глутамін (0,092 у.о.), піруват 
(0,113 у.о.), $\alpha$-кетоглутарат (0,113 у.о.), сукцинат $(0,152$ у.о.), диметил- $\alpha$-кетоглутарат $(0,156$ у.о.), монометил-сукцинат (0,172 у.о.). Адаптаційна здатність мітохондрій гепатоцитів частково залежить від спорідненості транспортерів плазматичної мембрани $\left(K_{\mathrm{m}}\right)$ до субстратів окислення. Наявність глюкози в середовищі не покращує адаптаційну здатність мітохондрій печінки.

К л ю ч о в і с л о в а: адаптаційна здатність мітохондрій, субстрати окислення, гепатоцити, FCCP.

\section{References}

1. Yadava N, Nicholls DG. Spare respiratory capacity rather than oxidative stress regulates glutamate excitotoxicity after partial respiratory inhibition of mitochondrial complex I with rotenone. J Neurosci. 2007; 27(27): 7310-7317.

2. Nicholls DG. Oxidative stress and energy crises in neuronal dysfunction. Ann NY Acad Sci. 2008; 1147: 53-60.

3. Sansbury BE, Jones SP, Riggs DW, DarleyUsmar VM, Hill BG. Bioenergetic function in cardiovascular cells: the importance of the reserve capacity and its biological regulation. Chem Biol Interact. 2011; 191(1-3): 288-295.

4. Hill BG, Higdon AN, Dranka BP, DarleyUsmar VM. Regulation of vascular smooth muscle cell bioenergetic function by protein glutathiolation. Biochim Biophys Acta. 2010; 1797(2): 285-295.

5. Lee WS, Sokol RJ. Liver disease in mitochondrial disorders. Semin Liver Dis. 2007; 27(3): 259-273.

6. Simões ICM, Fontes A, Pinton P, Zischka H, Wieckowski MR. Mitochondria in non-alcoholic fatty liver disease. Int J Biochem Cell Biol. 2018; 95: 93-99.

7. Abdelmalek MF, Lazo M, Horska A, Bonekamp S, Lipkin EW, Balasubramanyam A, Bantle JP, Johnson RJ, Diehl AM, Clark JM. Higher dietary fructose is associated with impaired hepatic adenosine triphosphate homeostasis in obese individuals with type 2 diabetes. Hepatology. 2012; 56(3): 952-960.

8. Karim S, Adams DH, Lalor PF. Hepatic expression and cellular distribution of the glucose transporter family. World J Gastroenterol. 2012; 18(46): 6771-6781.
9. Poole RC, Halestrap AP. Transport of lactate and other monocarboxylates across mammalian plasma membranes. Am J Physiol. 1993; 264(4 Pt 1): C761-C782.

10. Fafournoux $P$, Demigné $C$, Rémésy $C$, Le Cam A. Bidirectional transport of glutamine across the cell membrane in rat liver. Biochem $J$. 1983; 216(2): 401-408.

11. Zimmerli B, O'Neill B, Meier PJ. Identification of sodium-dependent and sodium-independent dicarboxylate transport systems in rat liver basolateral membrane vesicles. Pflugers Arch. 1992; 421(4): 329-335.

12. Seglen PO. Preparation of isolated rat liver cells. Methods Cell Biol. 1976; 13: 29-83.

13. Shinoda Y, Suzuki T, Sugawara-Yokoo M, Nagamatsu S, Kuwano H, Takata K. Expression of sugar transporters by in vivo electroporation and particle gun methods in the rat liver: localization to specific membrane domains. Acta Histochem Cytochem. 2001; 34(1): 15-24.

14. Asano T, Katagiri H, Tsukuda K, Lin JL, Ishihara H, Yazaki Y, Oka Y. Upregulation of GLUT2 mRNA by glucose, mannose, and fructose in isolated rat hepatocytes. Diabetes. 1992; 41(1): 22-25.

15. Rencurel F, Waeber G, Antoine B, Rocchiccioli F, Maulard P, Girard J, Leturque A. Requirement of glucose metabolism for regulation of glucose transporter type 2 (GLUT2) gene expression in liver. Biochem J. 1996; 314(Pt 3): 903-909.

16. Uldry M, Ibberson M, Hosokawa M, Thorens B. GLUT2 is a high affinity glucosamine transporter. FEBS Lett. 2002; 524(1-3): 199-203.

17. McCommis KS, Finck BN. Mitochondrial pyruvate transport: a historical perspective and future research directions. Biochem J. 2015; 466(3): 443-454.

18. Rui L. Energy metabolism in the liver. Compr Physiol. 2014; 4(1): 177-197.

19. Bonen A, Heynen M, Hatta H. Distribution of monocarboxylate transporters MCT1-MCT8 in rat tissues and human skeletal muscle. Appl Physiol Nutr Metab. 2006; 31(1): 31-39.

20. Baird FE, Beattie KJ, Hyde AR, Ganapathy V, Rennie MJ, Taylor PM. Bidirectional substrate fluxes through the system N (SNAT5) glutamine transporter may determine net glutamine flux in rat liver. $J$ Physiol. 2004; 559(Pt 2): 367-381. 
21. Bhutia YD, Ganapathy V. Glutamine transporters in mammalian cells and their functions in physiology and cancer. Biochim Biophys Acta. 2016; 1863(10): 2531-2539.

22. Moseley RH, Jarose S, Permoad P. Hepatic $\mathrm{Na}(+)$-dicarboxylate cotransport: identification, characterization, and acinar localization. Am $J$ Physiol. 1992; 263(6 Pt 1): G871-G879.

23. Stoll B, Hüssinger D. Functional hepatocyte heterogeneity. Vascular 2-oxoglutarate is almost exclusively taken up by perivenous, glutaminesynthetase-containing hepatocytes. Eur $J$ Biochem. 1989; 181(3): 709-716.

24. Stoll B, McNelly S, Buscher HP, Häussinger D. Functional hepatocyte heterogeneity in glutamate, aspartate and $\alpha$-ketoglutarate uptake: a histoautoradiographical study. Hepatology. 1991; 13(2): 247-253.

25. Chen X, Tsukaguchi H, Chen XZ, Berger UV, Hediger MA. Molecular and functional analysis of SDCT2, a novel rat sodium-dependent dicarboxylate transporter. J Clin Invest. 1999; 103(8): 1159-1168.

26. Rognstad R. Gluconeogenesis in rat hepatocytes from monomethyl succinate and other esters. Arch Biochem Biophys. 1984; 230(2): 605-609.

27. Edlund GL, Halestrap AP. The kinetics of transport of lactate and pyruvate into rat hepatocytes. Evidence for the presence of a specific carrier similar to that in erythrocytes. Biochem J. 1988; 249(1): 117-126.

28. Jackson VN, Halestrap AP. The kinetics, substrate, and inhibitor specificity of the monocarboxylate (lactate) transporter of rat liver cells determined using the fluorescent intracellular $\mathrm{pH}$ indicator, 2',7'-bis(carboxyethyl)-5(6)-carboxyfluorescein. J Biol Chem. 1996; 271(2): 861-868.

29. Thorens B, Cheng ZQ, Brown D, Lodish HF. Liver glucose transporter: a basolateral protein in hepatocytes and intestine and kidney cells. Am J Physiol. 1990; 259(6 Pt 1): C279-C285. 